\title{
Effects of Nitrogen Fertilization and Frequency of Cutting on the Yield and Composition of Guinea Grass in Puerto Rico ${ }^{1}$
}

\author{
José Vicente-Chandler, Servando Silva, and Jacinto Figarella ${ }^{2}$
}

\section{INTRODUCTION}

Guinea grass (Panicum maximum) (fig. 1) is one of the most widely used and versatile forage grasses of the Tropics, thriving under widely varying soil and climatic conditions. In Puerto Rico, it is the most extensively used of the improved grasses. On this densely populated Island, it is essential that high yields of forage be produced per unit of land.

Despite the importance of Guinea grass as a forage crop, little is known regarding the effects of nitrogen fertilizer or frequency of cutting on yield and composition of this grass. Watkins and Lewy $(6)^{3}$ in San Salvador, found that Guinea grass yielded progressively more when cut at 1-, 2-, and 3-month intervals. Rivera-Brenes (2) in Puerto Rico, however, reported that Guinea grass yielded more when cut at 40-day intervals than when cut at intervals of 3 and 4 months, and that the lignin content increased while the protein content decreased with length of harvest interval.

Rodriguez ( 3 ) in Puerto Rico, found that the application of 200 pounds of nitrogen per acre yearly more than doubled the yields of Guinea grass growing in the humid region. Vicente and Figarella (5) in Puerto Rico, found that the application of 100 pounds of nitrogen per acre to Guinea grass growing in the semiarid region increased yields by about one-third, while Vicente, et al. (4), reported that applications of 300 pounds of nitrogen per acre yearly more than doubled the yields of irrigated Guinea grass.

This paper presents the results of an experiment carried out to characterize the response of Guinea grass to nitrogen fertilization as affected by frequency of cutting and season of the year. The effects of treatments on forage composition and on soil acidity were also studied.

\section{MATERIALS AND METHODS}

The experiment was carried out at Río Piedras, over 2 consecutive years. The mean annual temperature is about $76^{\circ} \mathrm{F}$, with seasonal variations

1 This work was carried out cooperatively between the U. S. Department of Agriculture and the Agricultural Experiment Station of the University of Puerto Rico.

2 Project Supervisor, Physical Science Aid, and Soil Scientist, respectively, Soil and Water Conservation Research Division, Agricultural Research Service, U. S. Department of Agriculture.

${ }^{3}$ Italic numbers in parentheses refer to Literature Cited, p. 239. 
of less than $10^{\circ} \mathrm{F}$. Rainfall totalled 102.6 and 56.3 inches during the first and second years, respectively, representing close to record deviations from the long-time average of about 80 inches.

The soil is a Fajardo clay, a deep, red, fairly well-drained soil, on about a 20-percent slope. Initially, the surface 6 inches averaged 3.2 percent of

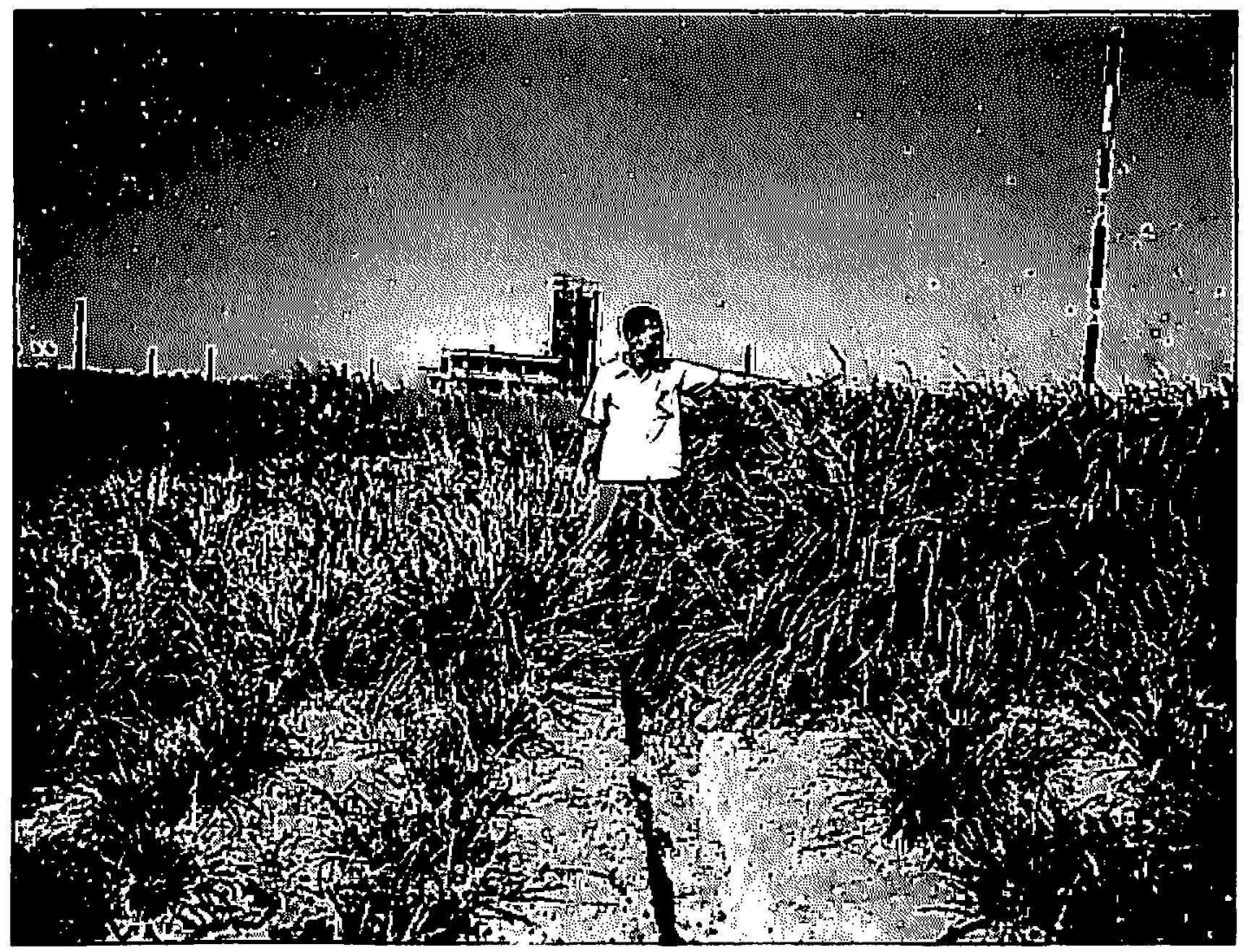

FIG. 1.-Sixty-day-old Guinea grass showing the effects of nitrogen fertilization. Results clockwise from plot at lower left: Nitrogen applied at rates of 0,200 , and 400 pounds per acre yearly in 6 equal applications.

organic matter, 0.17 percent of nitrogen, 12.1 m.e. exchange capacity, and 6.0 m.e. of exchangeable bases per $100 \mathrm{gm}$. of soil, and had a $\mathrm{pH}$ of 4.8 .

The treatments used were as follows:

\section{Harvest intervals \\ (Days)}

40

60

90
Nitrogen levels

(Pounds $N$ per acre yearly)

0

200

400

800

1,600

All combinations of these treatments were tested using a split-plot design, with harvest intervals as the main plots and nitrogen levels as the subplots. All treatments were replicated four times. Subplots were 
$10 \times 20$ feet, surrounded by ditches to prevent fertilizer from washing into adjoining plots.

The upper 6 inches of soil in all plots was limed to a $\mathrm{pH}$ of about 6.5 at the start of the experiment. Blanket additions of phosphorus and potassium were made at the rate of 300 pounds of $\mathrm{P}_{2} \mathrm{O}_{5}$ per acre from 20-percent superphosphate in one application and 600 pounds $\mathrm{K}_{2} \mathrm{O}$ from $\mathrm{KCl}$ per acre annually in four to nine equal applications, depending on frequency of cutting. The nitrogen was applied as ammonium sulfate in four to nine equal applications yearly, depending on frequency of cutting.

The grass was cut at the prescribed intervals, weighed, and the forage removed from the plots. Samples from each plot at every harvest were analyzed for dry matter and total nitrogen. The crude-protein content was calculated using the factor 6.25 times N. Samples were composited by plots at the end of the first year and analyzed for calcium, phosphorus, potassium, magnesium, and lignin. Yields were taken over three 60-day periods, after terminating the experiment, to determine the residual effects of the treatments.

At the end of the experiment the soil in all plots cut every 60 days and receiving $0,400,800$, and 1,600 pounds of nitrogen per acre yearly was sampled at 6-inch intervals to a depth of 2 feet and analyzed for $\mathrm{pH}$ and exchangeable bases.

\section{RESULTS}

\section{EFFECT OF LENGTH OF HARVEST INTERVAL}

The data in table 1 and figure 2 show that yields increased markedly with length of harvest interval. At the 800-pound level of nitrogen, Guinea grass produced $27,552,32,733$, and 43,608 pounds of dry matter per acre yearly when cut at 40-, 60-, and 90-day intervals, respectively. The drymatter content of the forage also increased with harvest intervals, averaging $20.2,23.8$, and 30.4 percent for these cutting intervals, respectively.

The protein content of the forage, however, dropped with each increase in harvest interval, averaging at the 800-pound level of nitrogen, 11.1, 9.6, and 7.3 percent when the grass was cut at 40,60 , and 90 days, respectively. Frequency of cutting had little effect on protein yields, however.

The proportion of applied nitrogen recovered in the forage, and the pounds of dry matter produced per pound of fertilizer nitrogen, tended to increase with length of harvest interval.

The data in table 2 show that the phosphorus, calcium, and potassium contents of the forage decreased with length of harvest interval, while the magnesium content showed a similar tendency. The phosphorus content of the forage averaged $0.35,0.26$, and 0.21 percent; the calcium content 0.93 , 0.77 and 0.60 percent, and the potassium content $2.00,1.78$, and 0.98 
percent, with a 40-, 60-, and 90-day interval respectively. The relatively high calcium content of Guinea grass is worthy of note.

The lignin content of the forage increased with length of harvest interval

TABLE 1.-The effects of nitrogen fertilization and frequency of culting on the yield and protein content of Guinea grass and on the efficiency of utilization of the applied nitrogen over a \&-year period

\begin{tabular}{|c|c|c|c|c|c|c|}
\hline $\begin{array}{c}\text { Nitrogen } \\
\text { applied per acre } \\
\text { yearly }\end{array}$ & $\begin{array}{l}\text { Yield of green } \\
\text { forage per acre } \\
\text { yearly }\end{array}$ & $\begin{array}{c}\text { Yield of dry } \\
\text { matter per acre } \\
\text { yearly }\end{array}$ & $\begin{array}{c}\text { Crude-protein } \\
\text { content }\end{array}$ & $\begin{array}{c}\text { Crude-protein } \\
\text { yield per acre } \\
\text { yearly }\end{array}$ & $\begin{array}{l}\text { Recovery of } \\
\mathrm{N} \text { in forage }\end{array}$ & $\begin{array}{l}\text { Dry matter } \\
\text { produced per } \\
\text { pound of each } \\
\text { increment of } \\
\mathbf{N}\end{array}$ \\
\hline
\end{tabular}

Grass cut every 40 days

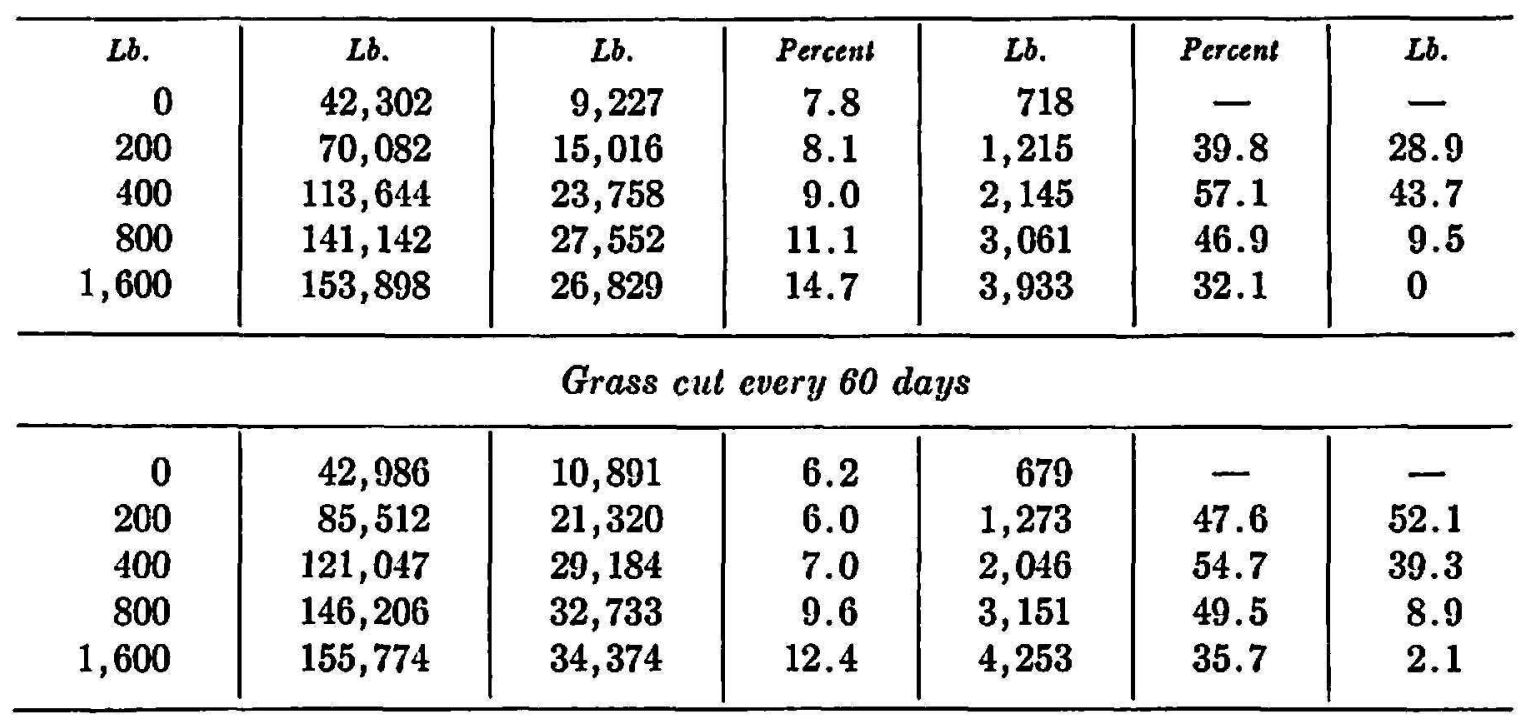

Grass cut every 90 days

\begin{tabular}{r|r|r|r|r|r|r}
\hline 0 & 45,380 & 13,195 & 4.9 & 647 & - & - \\
200 & 98,342 & 31,015 & 5.0 & 1,553 & 72.5 & 89.1 \\
400 & 115,982 & 36,910 & 5.6 & 2,055 & 56.3 & 29.5 \\
800 & 143,088 & 43,608 & 7.3 & 3,191 & 51.0 & 16.7 \\
1,600 & 166,324 & 48,259 & 9.9 & 4,777 & 41.3 & 5.8 \\
\hline
\end{tabular}

averaging $7.89,9.49$, and 10.76 percent when the grass was cut every 40 , 60 , and 90 days, respectively.

Less weeding was required with the longer harvest intervals.

EFFECT OF NITROGEN FERTILIZATION

The data in table 1 and figure 2 show that yields increased rapidly with nitrogen fertilization up to at least the 400-pound level at all harvest intervals. With a 60-day harvest interval, yields were almost tripled to 29,184 pounds of dry matter per acre yearly by the application of 400 pounds of nitrogen (table 1). A detailed analysis of the data shows that 
TABLE 2.-The effects of nitrogen fertilization and harvest intervals on the mineral and lignin contents of Guinea grass and on withdrawal of nutrients in forage

\begin{tabular}{|c|c|c|c|c|c|c|c|c|}
\hline \multirow{3}{*}{$\begin{array}{l}\text { Nitrogen fertiliz- } \\
\text { ation (pounds } N \\
\text { per acre yearly) }\end{array}$} & \multicolumn{8}{|c|}{ Results at harvest intervals indicated } \\
\hline & \multicolumn{2}{|c|}{40 days } & \multicolumn{2}{|c|}{60 days } & \multicolumn{2}{|c|}{90 days } & \multicolumn{2}{|c|}{ Average } \\
\hline & $\begin{array}{l}\text { Percent- } \\
\text { age com- } \\
\text { position? }\end{array}$ & $\begin{array}{c}\text { Pounds } \\
\text { withdrawn } \\
\text { per acre } \\
\text { ycarly }\end{array}$ & $\begin{array}{l}\text { Percent- } \\
\text { age com- } \\
\text { position? }\end{array}$ & $\begin{array}{c}\text { Pounds } \\
\text { withdrawn } \\
\text { per acre } \\
\text { yearly }\end{array}$ & $\begin{array}{l}\text { Percent- } \\
\text { age com- } \\
\text { position: }\end{array}$ & $\begin{array}{c}\text { Pounds } \\
\text { withdrawn } \\
\text { per acre } \\
\text { yearly }\end{array}$ & $\begin{array}{l}\text { Percent- } \\
\text { age com- } \\
\text { position: }\end{array}$ & $\begin{array}{c}\text { Pounds } \\
\text { withdrawn } \\
\text { per acre } \\
\text { yearly. }\end{array}$ \\
\hline \multicolumn{9}{|c|}{ Nitrogen } \\
\hline $\begin{array}{r}0 \\
400 \\
800\end{array}$ & $\begin{array}{l}1.30 \\
1.44 \\
1.65\end{array}$ & $\begin{array}{l}124.9 \\
334.9 \\
453.3\end{array}$ & $\begin{array}{l}1.01 \\
1.09 \\
1.42\end{array}$ & $\begin{array}{l}107.6 \\
315.7 \\
500.7\end{array}$ & $\begin{array}{r}0.74 \\
.82 \\
1.07\end{array}$ & $\begin{array}{r}91.2 \\
294.6 \\
471.3\end{array}$ & $\begin{array}{l}1.01 \\
1.12 \\
1.38\end{array}$ & $\begin{array}{l}107.9 \\
315.1 \\
475.1\end{array}$ \\
\hline Average & 1.46 & 304.4 & 1.17 & 308.0 & .87 & 285.7 & & \\
\hline \multicolumn{9}{|c|}{ Phosphorus } \\
\hline $\begin{array}{r}0 \\
400 \\
800\end{array}$ & $\begin{array}{r}0.45 \\
.37 \\
.24\end{array}$ & $\begin{array}{l}43.2 \\
83.5 \\
65.9\end{array}$ & $\begin{array}{r}0.38 \\
.22 \\
.19\end{array}$ & $\begin{array}{l}40.5 \\
63.2 \\
70.0\end{array}$ & $\begin{array}{r}0.31 \\
.16 \\
.15\end{array}$ & $\begin{array}{l}38.2 \\
57.5 \\
66.1\end{array}$ & $\begin{array}{r}0.38 \\
.25 \\
.19\end{array}$ & $\begin{array}{l}40.6 \\
68.2 \\
67.3\end{array}$ \\
\hline Average & 0.35 & 64.2 & 0.26 & 57.9 & 0.21 & 53.9 & & \\
\hline
\end{tabular}

Calcium

\begin{tabular}{|c|c|c|c|c|c|c|c|c|}
\hline $\begin{array}{r}0 \\
400 \\
800\end{array}$ & $\begin{array}{r}0.92 \\
.88 \\
.98\end{array}$ & $\begin{array}{r}88.4 \\
108.5 \\
269.2\end{array}$ & $\begin{array}{r}0.71 \\
.78 \\
.81\end{array}$ & $\begin{array}{r}75.6 \\
225.9 \\
285.6\end{array}$ & $\begin{array}{r}0.52 \\
.64 \\
.65\end{array}$ & $\begin{array}{r}64.1 \\
229.9 \\
286.3\end{array}$ & $\begin{array}{r}0.72 \\
.77 \\
.81\end{array}$ & $\begin{array}{r}76.0 \\
218.1 \\
280.4\end{array}$ \\
\hline Average & 0.93 & 185.4 & 0.77 & 195.7 & 0.60 & 103.4 & & \\
\hline \multicolumn{9}{|c|}{ Potassium } \\
\hline $\begin{array}{r}0 \\
400 \\
800\end{array}$ & $\begin{array}{l}2.00 \\
1.80 \\
2.21\end{array}$ & $\begin{array}{l}192.2 \\
406.1 \\
607.7\end{array}$ & $\begin{array}{l}1.56 \\
2.08 \\
1.70\end{array}$ & $\begin{array}{l}166.1 \\
249.3 \\
599.4\end{array}$ & $\begin{array}{r}1.17 \\
.95 \\
.82\end{array}$ & $\begin{array}{l}144.1 \\
341.3 \\
361.2\end{array}$ & $\begin{array}{l}1.58 \\
1.61 \\
1.58\end{array}$ & $\begin{array}{l}167.5 \\
332.2 \\
522.6\end{array}$ \\
\hline Average & 2.00 & 402.0 & 1.78 & 338.3 & 0.98 & 282.2 & & \\
\hline \multicolumn{9}{|c|}{ Magnesium } \\
\hline $\begin{array}{r}0 \\
400 \\
800\end{array}$ & $\begin{array}{r}0.40 \\
.49 \\
.47\end{array}$ & $\begin{array}{r}38.4 \\
110.5 \\
129.1\end{array}$ & $\begin{array}{r}0.32 \\
.38 \\
.48\end{array}$ & $\begin{array}{r}34.1 \\
110.1 \\
169.2\end{array}$ & $\begin{array}{r}0.35 \\
.33 \\
.40\end{array}$ & $\begin{array}{r}43.1 \\
118.6 \\
176.2\end{array}$ & $\begin{array}{r}0.36 \\
.40 \\
.45\end{array}$ & $\begin{array}{r}38.6 \\
113.1 \\
158.2\end{array}$ \\
\hline Average & 0.45 & 92.7 & 0.39 & 104.5 & 0.36 & 112.6 & & \\
\hline
\end{tabular}

Lignin

\begin{tabular}{|c|c|c|c|c|c|c|c|c|}
\hline $\begin{array}{r}0 \\
400 \\
800\end{array}$ & $\begin{array}{l}7.08 \\
8.20 \\
8.38\end{array}$ & - & $\begin{array}{r}8.41 \\
9.43 \\
10.64\end{array}$ & - & $\begin{array}{r}8.97 \\
11.43 \\
11.87\end{array}$ & - & $\begin{array}{r}8.15 \\
9.69 \\
10.30\end{array}$ & - \\
\hline Average & 7.89 & - & 9.49 & - & 10.76 & - & & \\
\hline
\end{tabular}

${ }^{1}$ All values are averages of 4 replications composited from all cuttings over a full 1-year period.

2 On dry-weight basis. 
yields increased with nitrogen fertilization up to the 400-pound level even during dry seasons of slow growth. Whenever the weather was favorable, a strong response in yield was evident up to the 800-pound level of nitrogen. Similarly, figure 2 shows that during the very dry year of 1957 the yield curve levelled off at the 400-pound level of nitrogen, whereas a strong response up to the 800-pound level was evident during 1956 when there was abundant rainfall.

The protein content of the forage increased with nitrogen rates up to the highest level tested, averaging when cut every 60 days, $6.2,7.0,9.6$, and 12.4 percent when fertilized with $0,400,800$, and 1,600 pounds of nitrogen per acre yearly, respectively. The highest protein content of 14.7

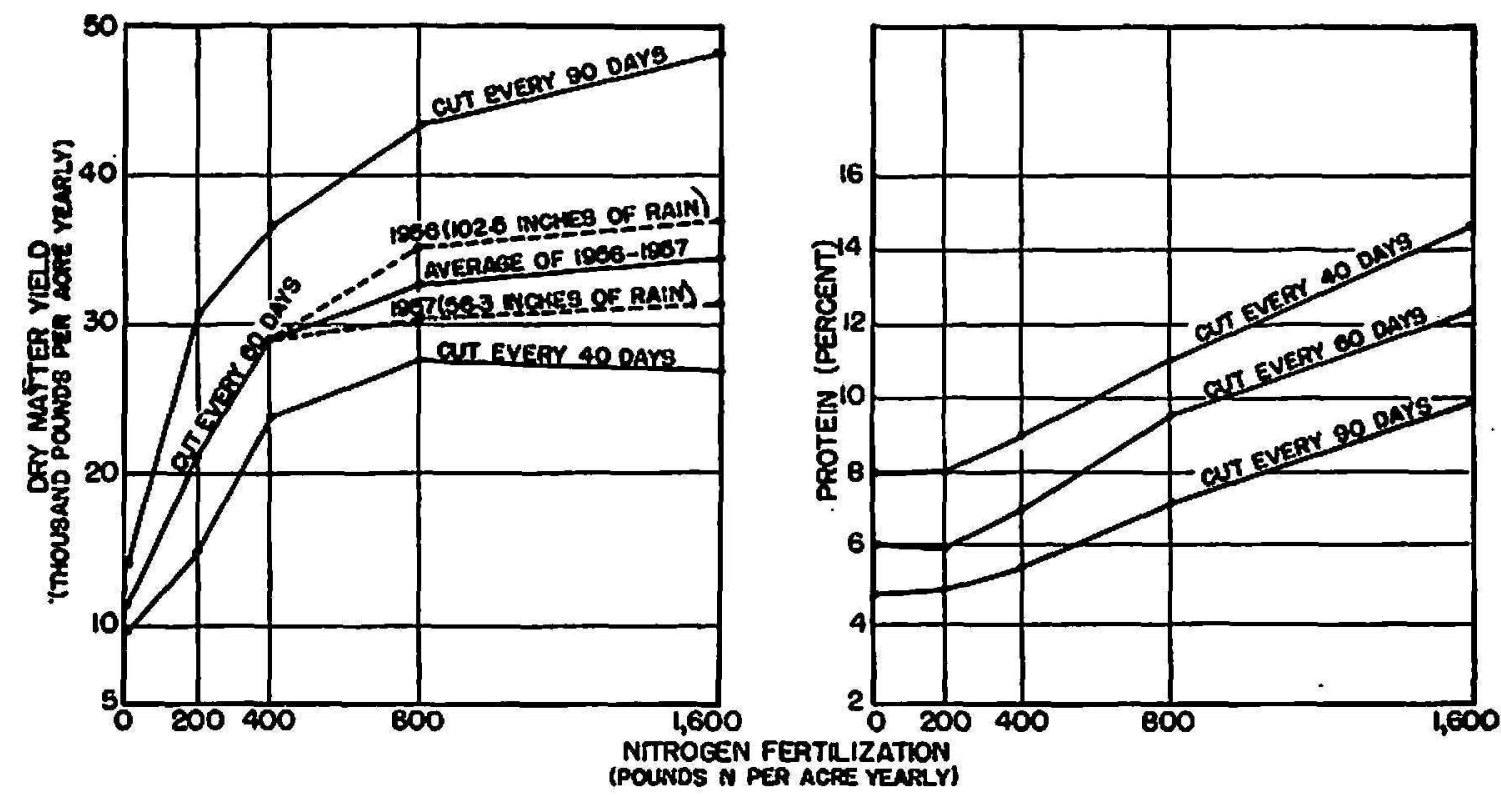

FIG. 2.-Effects of nitrogen fertilization and frequency of cutting on yield and protein content of Guinen grass.

percent was attained with a 40-day harvest interval and 1,600 pounds of nitrogen per acre yearly. The assumption is made that the nitrogen was essentially all in the amino form since no more than traces of nitrates were found in the forage.

Protein yields increased rapidly with nitrogen fertilization up to the maximum level tested, averaging with a 60-day harvest interval, 679, $2,046,3,151$, and 4,253 pounds per acre yearly at the $0-, 400-, 800$-, and 1,600-pound levels of nitrogen, respectively.

The data in table 1 show that, generally, about half of the applied nitrogen was recovered in the forage when 800 pounds or less were applied per acre yearly, with a lower recovery at the 1,600-pound rate. If residual yields are considered, recovery of fertilizer nitrogen would average about 4 percent higher. Guinea grass obtained about 100 pounds of nitrogen from the soil per acre yearly when none was applied as fertilizer. 
The efficiency of utilization of fertilizer nitrogen decreased rapidly with increasing rates. With a 60-day harvest interval, 52.1, 39.3, 8.9, and 2.1 pounds of dry matter were produced per pound of each successive increment of nitrogen.

The data in table 2 show that the phosphorus content of the forage decreased with increased nitrogen rates at all harvest intervals, averaging $0.38,0.25$, and 0.19 percent at the $0-, 400-$, and 800 -pound levels of nitrogen, respectively. Nitrogen rates had no apparent effect on the calcium, potassium, or magnesium contents of the forage. The lignin content of the forage, however, increased significantly with nitrogen rates, averaging with a 60-day harvest interval, 8.41, 9.43, and 10.64 percent at the 0-, 400-, and 800-pound levels, respectively.

Nitrogen fertilization reduced weed growth. Plots cut every 60 days and fertilized with 400 pounds or more of nitrogen per acre yearly required no weeding.

\section{NUTRIENT WITHDRAWAL AT HIGH YIELD LEVELS}

Table 2 shows that intensively managed Guinea grass withdraws large amounts of nutrients, particularly nitrogen and potassium. With a 60-day harvest interval and an 800-pound rate of nitrogen, about 70 pounds of phosphorus, 286 pounds of calcium, 169 pounds of magnesium, and 500 pounds of nitrogen were removed per acre yearly in the forage. About 600 pounds of potassium were also withdrawn, but much of this represented luxury consumption. Recent experiments by the authors indicate that, with optimum fertilization, Guinea grass contains about 1 percent of potassium rather than the 1.7 percent found in the trials under discussion. Thus, about 330 pounds of potassium would have been withdrawn per acre yearly if optimum potassium levels had been used. From the above it is apparent that heavy fertilization is required to sustain high yields.

Nutrient withdrawal increased greatly with nitrogen rates, but was not strongly affected by frequency of cutting. Withdrawal of calcium and potassium was more than tripled, of phosphorus almost doubled, of magnesium about quadrupled, and of nitrogen almost quintupled, when nitrogen rates were raised from 0 to 800 pounds per acre yearly with a 60-day harvest interval.

\section{RESIDUAL EFFECTS ON YIELDS}

Plots harvested at 90-day intervals during the course of the experiment yielded about 30 percent more over a 60-day period ending 6 months after the experiment was terminated, than plots formerly harvested at 40 - and 60 -day intervals. The differences were more marked at low nitrogen rates.

Higher residual yields were produced by plots receiving heavy nitrogen applications during the course of the experiment. The following tabulation 
shows the effect of nitrogen rates used during the course of the experiment on yields and protein content of forage produced over a 60-day period ending 8 months after the last application of nitrogen.

Nitrogen level

0
200
400
800
1,600

Pounds of dry malter per acre

$$
1,040
$$$$
1,350
$$$$
1,400
$$$$
2,300
$$$$
3,700
$$

\section{Percentage of protein}

6.7

7.3

7.4

8.4

13.6

\section{EFFECT OF SEASON OF THE YEAR}

Approximately the same yields were produced during the second year when rainfall totalled 56.3 inches as during the first year with a rainfall of 102.6 inches, but seasonal yields varied considerably.

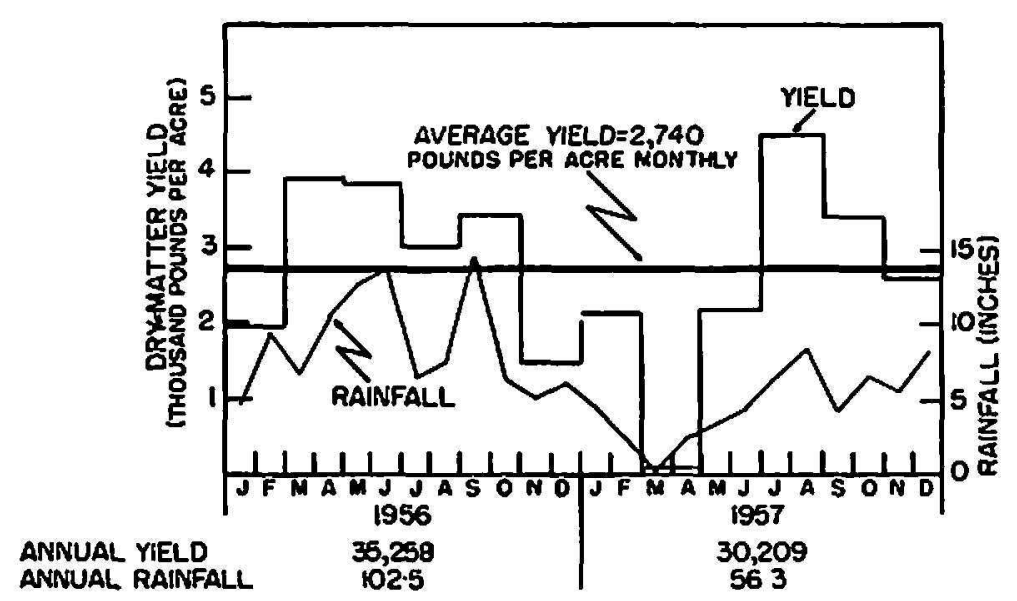

FIG. 3.-Effects of season of the year and of rainfall on yields of Guinea grass cut every 60 days and fertilized with 800 pounds of nitrogen per acre yearly.

Figure 3 shows that season of the year, largely as a result of rainfall, had a marked effect on forage production. November, December, January, and February yields were below average, while July, August, September, and October yields exceeded the average during both years. March, April, May, and June yields were far below average in 1957 as a result of the driest spring on record at Río Piedras.

Protein content of the forage also varied considerably with season of the year, ranging with a 60 -day harvest interval and 800 pounds of nitrogen, from as low as 7.4 percent to as high as 11.2 percent. In general, protein content was highest during seasons of low yields and vice versa.

\section{EFFECT OF HEAVY APPLICATIONS OF AMMONIUM SULFATE ON SOIL REACTION AND BASE STATUS}

Heavy applications of ammonium sulfate had a strong effect on soil acidity and base status as shown by the data in table 3 . The application of 800 pounds of nitrogen per acre yearly as ammonium sulfate for 2 con- 
secutive years, reduced the $\mathrm{pH}$ of the upper 6 inches of soil from 6.7 to 4.6 and the exchangeable base content from 11.6 to 6.1 m.e. per $100 \mathrm{gm}$. of soil. At the 1,600-pound level of nitrogen, the $\mathrm{pH}$ was reduced to 4.0 and the exchangeable bases to 2.7 m.e. per $100 \mathrm{gm}$. of soil. The effect on base status of the soil was apparent to a considerable depth in the profile. There was no indication of an accumulation of bases in the lower horizons of soil. Abruña, Pearson, and Elkins (1), have discussed these results in detail. Nitrogen rates had no apparent effect on organic-matter content of the soil.

TABLE 3.-The effect of nitrogen fertilizer in the form of ammonium sulfate on the reaction and exchangeable-base status at different depths of a Fajardo clay planted to Guinea grass over a 2-year period ${ }^{1}$

\begin{tabular}{|c|c|c|c|c|c|c|}
\hline \multirow{2}{*}{ Depth (inches) } & \multicolumn{3}{|c|}{$\mathrm{pH}$ for- } & \multicolumn{3}{|c|}{$\begin{array}{l}\text { M.e. exchangeable bases per } 100 \mathrm{gm} \text {. } \\
\text { of soil for- }\end{array}$} \\
\hline & No $\mathbf{N}$ & $\begin{array}{l}800 \mathrm{lb} . \\
\mathrm{N} \text { per acre } \\
\text { yearly }\end{array}$ & $\begin{array}{c}1,600 \mathrm{lb} . \\
N^{\text {per acre }} \\
\text { yearly }\end{array}$ & No nitrogen & $\begin{array}{l}800 \mathrm{lb} . \\
\mathrm{N} \text { per acre } \\
\text { yearly }\end{array}$ & $\begin{array}{c}1,600 \mathrm{lb} . \\
\text { N per acre } \\
\text { yearly }\end{array}$ \\
\hline $0-6$ & 6.7 & 4.6 & 4.0 & 11.6 & 6.1 & 2.7 \\
\hline $6-12$ & 5.8 & 4.5 & 4.1 & 7.4 & 4.6 & 3.2 \\
\hline $12-18$ & 5.0 & 4.8 & 4.2 & 7.4 & 4.9 & 3.6 \\
\hline $18-24$ & 4.7 & 4.5 & 4.3 & 5.9 & 4.9 & 3.9 \\
\hline
\end{tabular}

${ }^{1}$ All values are averages of 4 replications.

\section{DISCUSSION}

Although highest yields were obtained when Guinea grass was cut every 90 days, the forage was of poor quality as indicated by the high lignin and relatively low protein and mineral contents. On the other hand; quality of the forage cut every 40 days was excellent. It is probably best to harvest Guinea grass every 40 to 60 days, using the shorter interval during seasons of fast growth. Guinea grass pastures may be grazed as often as every 30 days during periods of fast growth.

The application of at least 400 pounds of nitrogen per acre yearly was very profitable under the conditions of this experiment, if the reasoning in the preceding paper on Napier grass is accepted. During seasons of high rainfall and fast growth the application of up to 800 pounds of nitrogen per acre yearly appeared warranted.

With a 60-day harvest interval and 800 pounds of nitrogen per acre yearly, Guinea grass produced about 73 tons of green forage, or 32,733 pounds of dry matter per acre yearly with 9.6 percent of protein. This is sufficient to meet the roughage requirements of about $4 \frac{1}{2}$ mature cows or steers. 
With proper management, yields of this magnitude can be obtained under widely different soil and climatic conditions found on the Island, provided moisture is adequate. In other experiments by the authors, properly managed Guinea grass yielded 28,482 pounds of dry matter per acre yearly on a steep Catalina clay in the mountain region, and 41,714 pounds of dry matter per acre yearly on a fertile, irrigated soil on the semiarid south coast.

The increase in lignin and decrease in protein and mineral contents of the forage with length of harvest interval is probably a normal result or maturity. The increase in protein content with nitrogen fertilization is to be expected, but the concurrent increase in lignin content is difficult to explain. The decrease in phosphorus content with nitrogen fertilization may have been caused by the dilution effect of higher yields in the presence of a relatively constant, limited amount of available phosphorus in the soil.

The data suggest that variations in forage production throughout the year could be reduced by using a longer harvest interval and heavier nitrogen fertilization during seasons of slow growth and a shorter harvest interval and low nitrogen fertilization during seasons of fast growth. However, applications in excess of a rate equivalent to 800 pounds of nitrogen per acre yearly during dry periods can cause burning and in some cases kill the grass. At high nitrogen rates, care should be taken not to apply the fertilizer directly on the clumps of grass.

The rapid increase in soil acidity resulting from heavy applications of ammonium sulfate indicate the need for annual applications of limestone to prevent loss of bases deep in the profile. The use of nitrogen sources having a lower residual acidity would reduce this loss.

\section{SUMMARY}

The effects of nitrogen rates ranging from 0 to 1,600 pounds of $N$ per acre yearly and of 40-, 60-, and 90-day harvest intervals on the yield and composition of Guinea grass and on soil acjdity were determined for 2 consecutive years.

Yields increased with nitrogen fertilization up to the 800-pound level, while protein content and protein yields increased up to the 1,600-pound level. About half of the fertilizer nitrogen was recovered in the forage when 800 pounds or less were applied per acre yearly. Efficiency of utilization, in terms of dry matter produced per pound of nitrogen, decreased with increasing rates. The phosphorus content of the forage decreased while the lignin content increased with nitrogen rates. Fertilization with nitrogen had no apparent effect on the calcium, potassium, or magnesium content of the forage.

Yields and lignin content of the forage increased while the protein. 
phosphorus, calcium, magnesium, and potassium contents decreased with length of harvest interval.

A 60 -day harvest interval and 400 to 800 pounds of nitrogen per acre yearly, depending on rainfall, seemed to be the optimum combination. With the higher nitrogen rate, Guinea grass yielded 32,733 pounds of dry matter (about 73 tons of green forage) per acre yearly with 9.6 percent of protein. With this treatment Guinea grass removed about 70 pounds of phosphorus, 286 pounds of calcium, 169 pounds of magnesium, 500 pounds of nitrogen, and 330 pounds of potassium per acre yearly.

About the same yields were produced during each of the two years although rainfall varied greatly. Seasonal yields varied widely.

The application of 800 pounds of nitrogen as ammonium sulfate per acre annually over a 2-year period caused a drop of $2.1 \mathrm{pH}$ units and a loss of 5.5 m.e. of exchangeable bases per $100 \mathrm{gm}$. in the upper 6 inches of soil.

\section{RESUMEN}

Se estudió el efecto de aplicaciones de nitrógeno que variaban entre 0 , y 1,600 libras por cuerda por año y de intervalos de corte de 40,60, y 90 días, en el rendimiento y composición de la yerba Guinea (Panicum maximum), y en la acidez del suelo durante 2 años consecutivos.

Los rendimientos aumentaron con niveles de nitrógeno hasta 800 libras por cuerda por año. El contenido y rendimiento de proteína aumentó con niveles de nitrógeno hasta 1,600 libras por cuerda por año. Se recuperó en el forraje aproximadamente la mitad del nitrógeno aplicado hasta 800 libras por cuerda, pero la eficiencia de utilización expresada en términos de forraje seco producido por cada libra de nitrógeno disminuyó según se aumentaban los niveles de nitrógeno. El contenido de fósforo disminuyó, pero el de lignina aumentó al aumentar los niveles de nitrógeno. El contenido de calcio, potasio, y magnesio en el forraje no se afectó con las aplicaciones de nitrógeno.

Los rendimientos de forraje seco y el contenido de lignina aumentaron al alargarse los intervalos de corte. Sin embargo, el contenido de proteína, fósforo, calcio, magnesio, y potasio disminuyó según se alargaron los intervalos de corte.

Un intervalo de corte de 60 días y de 400 a 800 libras de nitrógeno por cuerda por año dependiendo de la abundancia de lluvia parece ser el tratamiento óptimo con 800 libras de nitrógeno al año, la yerba Guinea produjo 32,738 libras de materia seca (como 73 toneladas de forraje verde) por cuerda por año, con un contenido de proteína de 9.6 por ciento. Con este tratamiento, la yerba extrajo del suelo 500 libras de nitrógeno, 330 libras de potasio, 286 libras de calcio, 169 libras de magnesio, y 70 libras de fósforo por cuerda por año. 
El rendimiento no varió apreciablemente durante los 2 años de experimentación, pero la producción varió considerablemente durante distintas épocas del año.

La aplicación de 800 libras de nitrógeno, en forma de sulfato amónico, por cuerda por año durante 2 años, redujo el $\mathrm{pH}$ de las 6 pulgadas de superficie en 2.1 unidades y acarreó una pérdida de 5.4 miliquievalentes de bases intercambiables por cada 100 gramos de suelo.

\section{LITERATURE CITED}

1. Abruña, F., Pearson, R. W., and Elkins, C., Quantitative evaluation of soil reaction and base status changes resulting from field applications of residual acid nitrogen fertilizer, Soil Sci. Soc. Amer. Proc. 22 (6) 539-42, 1958.

2. Rivera-Brenes, L., Technical and Economic Aspects of Roughage Production in Puerto Rico, Agr. Exp. Sta. Univ. P. R. Tech. Paper No. 12, 1953.

3. Rodriguez, J. P., Effect of nitrogen applications on the yields and composition of forage crops, J. Agr. Univ. P. R. 33(3) 98-117, 1949.

4. Vicente-Chandler, J., Rivera-Brenes, L., Caro-Costas, R., Pastor-Rodriguez, J., Boneta, E., and Gracia, W., The Management and Utilization of the Forage Crops of Puerto Rico, Agr. Exp. Sta., Univ. P. R., Bul. 116, 1953.

5. Vicente-Chandler, J., and Figarella, J., Growth characteristics of Guinea grass on the semiarid south coast of Puerto Rico and the effect of nitrogen fertilization on forage yields and protein content, J. Agr. Univ. P. R., $42(3)$ 151-60, 1958.

6. Watkins, J. W., and Lewy-van Severin, M., Effect of frequency and height of cutting on the yield, stand and protein content of some forages in El Salvador, Agron. J. 43(6) 291-6, 1951. 